\title{
THE INFLUENCE OF ENTREPRENEURIAL PASSION AND CREATIVITY ON ENTREPRENEURIAL INTENTIONS
}

\author{
BERNARDO BIGNETTI ${ }^{1}$ \\ (iD) https://orcid.org/0000-0003-2608-2502 \\ ANA C. M. Z. SANTOS \\ (iD) https://orcid.org/0000-0003-3336-6001 \\ PETER B. HANSEN ${ }^{2}$ \\ (iD) https://orcid.org/0000-0003-2361-3574 \\ EDER HENRIQSON ${ }^{1}$ \\ (iD) https://orcid.org/0000-0003-1081-6583
}

To cite this paper: Bignetti, B., Santos, A. C. M. Z., Hansen, P. B., \& Henriqson, E. (2021). The influence of entrepreneurial passion and creativity on entrepreneurial intentions. Revista de Administração Mackenzie, 22(2), 1-32. doi:10.1590/1678-6971/eRAMR210082

Submission: Apr. 26, 2019. Acceptance: July 8, 2020.

1 Pontifical Catholic University of Rio Grande do Sul (PUCRS), Porto Alegre, RS, Brazil.

2 Federal University of Rio Grande do Sul (UFRGS), Porto Alegre, RS, Brazil.

\section{(c) $\mathbf{B Y}$




\section{ABSTRACT}

Purpose: This study aims to analyze the influence of entrepreneurial passion and creativity on entrepreneurial intent. It also examines the mediating role of entrepreneurial self-efficacy between the personal/ cognitive variable and entrepreneurial intention.

Originality/value: By stressing the importance of cognitive and emotional variables that may influence entrepreneurial intentions among university students (such as creativity and entrepreneurial passion), this study shows the important role that universities have in the development of entrepreneurial intent. According to the Social Cognitive Theory (SCT), the environment influences individual behavior and, therefore, universities should encourage an entrepreneurial environment, enabling the creation of new jobs and companies.

Design/methodology/approach: Data were collected through a survey with business and technology students from a Brazilian university. In total, 338 valid responses were obtained, which were analyzed through structural equation modeling. The data were collected in a cross-sectional manner and by a stratified and non-probability sampling method. To address the research hypothesis and to attain the objectives of the study, all constructs were adapted from relevant literature in the field of entrepreneurship. The structural model was examined in relation to the model fit, which enabled the hypothesis to be tested.

Findings: Results showed both a direct and indirect positive relationship between entrepreneurial passion on entrepreneurial intention. Regarding the creativity factor, results indicated only an indirect effect of creativity on entrepreneurial intention, this relationship being mediated through entrepreneurial self-efficacy. No significant differences were found in the model regarding age, gender, graduation program, entrepreneurial family background, role models or family income.

\section{KEYWORDS}

Entrepreneurial intention. Social Cognitive Theory. Creativity. Entrepreneurial passion. Self-efficacy. 


\section{INTRODUCTION}

Entrepreneurship has been an important topic of interest for public policy and for economic development ever since Schumpeter published his seminal work in the 1930s (Roy, Akhtar, \& Das, 2017). In developing countries, such as Brazil, entrepreneurship plays a key role in economic growth, job creation and social well-being (West, Bamford, \& Marsden, 2008). Before becoming an entrepreneur, there is the intention to become one. The psychological literature indicates that individual intention is a good predictor of planned behavior, such as the intention to become an entrepreneur (Krueger, Reilly, \& Carsrud, 2000). Therefore, scholars have been interested in understanding the main factors that could influence entrepreneurial intention, with regard to the role of context, institutions, personal and psychological factors (Liguori, Bendickson, \& McDowell, 2018; Liñán \& Fayolle, 2015).

Several antecedents of entrepreneurial intention have been identified and need to be further explored. These include entrepreneurial education (Souitaris, Zerbinati, \& Al-Laham, 2007), entrepreneurial self-efficacy (Bacq, Ofstein, Kickul, \& Gundry, 2017), creativity (Bellò, Mattana, \& Loi, 2018) and entrepreneurial passion (Cardon, Gregoire, Stevens, \& Patel, 2013). There is a demand for more research on the dynamic interaction between an individual's personal characteristics and the environmental context (Nabi, Walmsley, \& Holden, 2015). To address this research gap, the authors apply Social Cognitive Theory (SCT) developed by Bandura (1986) to capture personal and environmental factors that form entrepreneurial behavior. SCT considers the interaction between cognitive factors, personal factors, and environmental events to outline intentions that precede individual action.

Based on the above, we focus on the influence that entrepreneurial passion and creativity have on entrepreneurial intent, in the context of Brazil, a developing South American country. According to the Global Entrepreneurship Monitor (GEM) 2015-2016, Brazil is ranked eighth in the world in relation to total entrepreneurial activity (TEA). Research by the Brazilian Support Service for Micro and Small Enterprises (Sebrae) (2014), indicates that $99 \%$ of the Brazilian companies are micro, small and medium enterprises. Since most of the studies on entrepreneurial research focus on North American or European entrepreneurs (Bruton, Ahlstrom, \& Obloj, 2008), there is a demand to better understand the factors that influence entrepreneurial intention and entrepreneurial behavior in Brazil, the largest country of South America. Brazil has a peculiar culture and social gathering, influenced 
by traditions from native South American Indians, Afro-descendants and European immigrants (Dunn, 2014). In fact, there is a complex native construct known as "jeitinho brasileiro" (way of doing things) that has been associated with national individual creativity in problem-solving strategies (Rodrigues, Milfont, Ferreira, Porto, \& Fischer, 2011). Therefore, the factors that influence entrepreneurial intent in this context may be different from other cultures, potentially providing new insight into the field of entrepreneurship.

University students are potential entrepreneurs (Liñán, Urbano, \& Guerrero, 2011). In this study, our sample comprised undergraduate students from two different programs, studying two different subjects, one managerial and the other technical. The students attended a university located in southern Brazil, ranked 16th among the top universities in South America and ranked second best private university in Brazil, according to the Times Higher Education (THE), Latin American university ranking 2017. We aimed to examine whether there are differences in entrepreneurial passion, creativity and entrepreneurial intent in students from different programs. This was in response to a call from Rauch and Hulsink (2015) and Maresch, Harms, Kailer, and Wimmer-Wurm (2016) to explore other sources of intentions and behaviors related to entrepreneurship, contextual issues and distinctive types of entrepreneurial education considering different courses and/or graduation programs.

Thus, in this paper we address three main objectives: 1 . to analyze the influence of entrepreneurial passion and creativity on entrepreneurial intent; 2. to examine the mediating role of entrepreneurial self-efficacy in the personal/cognitive variable and entrepreneurial intention; 3 . to test for differences in the structural model in regard to control variables, such as age, gender, type of graduation program, graduation progress and risk propensity. By addressing these issues, this study advances the literature by examining whether entrepreneurial passion and creativity affect entrepreneurial intentions at the individual level in the context of a developing South American country. The study also assesses whether these effects are mediated by entrepreneurial self-efficacy and whether the control variables mentioned above influence the relationships tested in the proposed theoretical model. As such, this work may be helpful to Brazilian educationalists and policymakers who aim to encourage entrepreneurial behavior in students to boost economic activity among young people. 


\section{THEORETICAL FRAMEWORK AND HYPOTHESIS DEVELOPMENT}

Investigating the reasons why one individual starts an entrepreneurial venture or career, whilst others do not, is an important inquiry in entrepreneurship research (Krueger \& Day, 2010). It is possible to observe that entrepreneurial intention is probably the first step towards sustaining an idea for an entrepreneurial endeavor, guiding goal setting and commitment effort (Bird, 1988; Krueger et al., 2000; Liñán \& Chen, 2009).

The specific decision to begin an entrepreneurial undertaking is a complex work of interrelated factors, influenced by internal and external aspects (Biraglia \& Kadile, 2017). Thus, personal factors, intentions and actions towards entrepreneurship are affected by environmental circumstances. In essence, the SCT, formulated by Bandura $(1986,1999)$, demonstrates that 1. behavior, 2. cognitive and personal factors and 3. environmental conditions interact with each other in a bidirectional manner. Thus, SCT, a model of reciprocal causality, provides an effective theoretical framework to study entrepreneurial intention. It addresses the dynamics through which personal, cognitive and environmental factors interact during the decision process of launching an entrepreneurial venture.

The behavioral dimension of SCT considers the interaction between personal perceptions, past experiences, and contextual factors. It should be noted that past behaviors may affect future intentions and actions by increasing perceived self-efficacy (Biraglia \& Kadile, 2017). According to Wood and Bandura (1989, p. 364), perceived self-efficacy is "an individual self-regulatory mechanism that refers to people's beliefs in their ability to mobilize motivation, cognitive resources, and action paths required to have control over daily events". Entrepreneurial self-efficacy relates to the degree to which the individual believes that he or she is capable of performing the roles and tasks of an entrepreneur (Chen, Greene, \& Crick, 1998).

Personal factors in the SCT take the form of cognitive, affective and biological events (Bandura, 1999). They have an impact on the individual evaluation of the external environment and on the decision to adopt a specific behavior (Bandura, 1986; Wood \& Bandura, 1989). Therefore, these factors may be influenced by age, gender, education, vicarious experience, radical change experience, as well as prior experience as an entrepreneur, personality characteristics and abilities (Biraglia \& Kadile, 2017; Boyd \& Vozikis, 1994; Davidsson, 1995). 
Regarding the environmental dimension of the model, Bandura (1986, 1993) highlights that people are partly the product of their environment, being influenced by social and cultural circumstances. As a result, "environments can set the direction of personal development through the competences, values and interests these influences promote" (Wood \& Bandura, 1989, p. 365).

\subsection{Creativity}

Creativity refers to the individual ability to generate new and appropriate solutions to existing problems (Amabile, 1997). In entrepreneurship, creativity is attributed to the ability to generate or recognize ideas that have the potential to produce products and/or services (Ward, 2004). Due to its relation to the process of recognizing opportunity, creativity can be seen as a relevant factor for entrepreneurial intent or behavior (Hills, Shrader, \& Lumpkin, 1999).

The study of creativity has long been contemplated in the social and cognitive aspect of psychological research, since individuals develop their ideas through a social process of discussion and interpretation (Dimov, 2007). Furthermore, the cognitive approach considers ideas as a result of employing basic mental operations to existing knowledge structures (Baron 2007; Ward 2004). Past success and observing the success of other people in the same environment can influence one's individual creative perception, i.e., a personal factor in SCT (Bandura, 1986; Wood \& Bandura, 1989).

Previous studies have been inconclusive, indicating no significant effects of creativity on entrepreneurial intention (Gelderen et al., 2008). In research, investigating career anchors that lead to self-employment, Feldman and Bolino (2000) found that the creativity anchor was a primary motivation factor towards choosing self-employment. However, a study by Lee and Wong (2004) also using the career anchor framework, found mixed results in relation to the creative anchor, presenting no support that such an anchor relates positively to the intention to start a venture. Other studies have shown a direct effect of creativity on entrepreneurial intention (Zampetakis \& Moustakis, 2006). Recent research has indicated that the dynamics of this are more complex, existing other variables to account for (Bellò et al., 2018; Biraglia \& Kadile, 2017).

Creativity is affected by a regional environment that promotes diversity and creativity (Lee, Florida, \& Acs, 2004). Similarly, entrepreneurial intentions are also influenced by social, cultural and economic contexts (Liñán \& 
Chen, 2009). The concept of creativity in the Brazilian culture is similar to the the concept in the "Western culture", being viewed as a positive construct. However, Brazilian researchers have identified some barriers to the development of creativity, as a result of local cultural values and traditions implying resistance to new ideas, high necessity of practicality, risk aversion and passivity (Fleith, 2011). Hence, in the context being analyzed, we hypothesize:

- H1: Creativity is positively related to entrepreneurial intentions.

\subsection{Entrepreneurial passion}

Entrepreneurial passion has long been associated with entrepreneurship. It was even considered in Schumpeter's work in the early 1950s to explain entrepreneurial behavior, characterized by a propensity to take risks and a determination to pursue goals and dreams (Cardon, Wincent, Singh, \& Drnovsek, 2009). However, in the light of recent research by Cardon et al. (2013), Cardon, Zietsma, Saparito, Matherne, and Davis (2005), and Cardon et al. (2009), entrepreneurial passion has received a theoretical framework to better understand the role of passion in entrepreneurship (Thorgren \& Wincent, 2015).

According to Cardon et al. (2013), entrepreneurial passion refers to an intense positive feeling experienced by engagement in entrepreneurial activities that are associated with individual self-identity. The framework to measure entrepreneurial passion proposed by Cardon et al. (2013), was based on three role identities found at the core of the entrepreneurial process: inventor, founder, and developer. The inventor role identity relates to opportunity recognition, the founder concerns venture creation, and the developer, venture growth. Our research focuses on undergraduate students who are not yet entrepreneurs and on examining whether entrepreneurial passion and creativity influence entrepreneurial intention. Therefore, only the inventor role will be under scrutiny in this work. This role relates to the opportunity-recognition process, that is, the capacity to look for new market opportunities and provide new products or services (Cardon et al., 2013).

Within the SCT perspective, entrepreneurial passion constitutes a personal factor in the model proposed by Wood and Bandura (1989). Entrepreneurial passion has a motivational effect that can enable individuals to surmount obstacles and remain committed to established goals (Cardon et al., 2009). As a result, passion can lead a person to really focus on what needs to be done in the venture creation process, without over-thinking possible obstacles or future problems (Biraglia \& Kadile, 2017). 
Recent research has suggested a positive relationship between entrepreneurial passion and entrepreneurial intention (Biraglia \& Kadile, 2017; Stenholm \& Renko, 2016). Since it is a novel area to be explored in the field of entrepreneurship, more research is recommended to examine the effects of entrepreneurial passion on the intent to start an entrepreneurial endeavor (Miao, Qian, \& Ma, 2016). It seems plausible that entrepreneurial passion can influence entrepreneurial intention. Thus, we hypothesize:

- H2: Entrepreneurial passion is positively related to entrepreneurial intentions.

\subsection{Self-efficacy}

Self-efficacy has aroused great interest in academic research. It has been applied and investigated in various contexts since Bandura's first definition of SCT. In the entrepreneurial field of study, self-efficacy can be viewed as an individual's confidence in his or her abilities to successfully accomplish tasks and carry out the role of an entrepreneur (Chen et al., 1998).

The concept of self-efficacy has also been aggregated into other theories of intention and behavior applied in the study of entrepreneurial intention, broadening its application. As such, the Theory of Planned Behavior, by Ajzen (1991), which identifies three antecedents of intention, employs the self-efficacy idea in one of its antecedents, known as perceived behavioral control. In addition, Shapero and Sokol's Model of Entrepreneurial Event (1982), also utilizes the self-efficacy notion in the antecedent known as perceived feasibility.

Entrepreneurial self-efficacy appears to be a relevant explanatory variable in studies on entrepreneurial intention (McGee, Peterson, Mueller, \& Sequeira, 2009). In the SCT framework, self-efficacy is part of the behavioral dimension, being particularly influenced by the cultural environment (Bandura, 1999). Thus, considering the context being examined, we hypothesize:

- H3: Self-efficacy is positively related to entrepreneurial intentions.

Earlier studies have also identified self-efficacy as having an important mediator role in the development of students' intentions to become entrepreneurs (Tsai, Chang, \& Peng, 2016). Investigations have indicated, for example, that self-efficacy mediates variables such as risk propensity, previous entrepreneurial experience, and personality traits (Roy et al., 2017; Zhao, Seibert, \& Hills, 2005). 
Self-efficacy has been examined as a possible mediator role between creativity and entrepreneurial intention (Bellò et al., 2018; Zampetakis, Gotsi, Andriopoulos, \& Moustakis, 2011). Creativity alone may not be enough to propel the individual to undertake an entrepreneurial venture. It should be noted that people need to evaluate themselves as being capable of carrying out activities associated with entrepreneurship in order to develop intentions of starting a business (Biraglia \& Kadile, 2017; Zampetakis et al., 2011). Self-efficacy, as pointed out before, is affected by the cultural environment (Bandura, 1999). Thus, with respect to the context being studied, we hypothesize:

- H4: Self-efficacy mediates the relationship between creativity and entrepreneurial intention.

Passion has been positively related to mastering goals, that is, developing a competence in a certain activity or task that is seen in entrepreneurial behavior (Thorgren \& Wincent, 2015). Consequently, passion has been positively associated with entrepreneurial self-efficacy (Murnieks, Mosakowski, \& Cardon, 2012). In addition, a study by Biraglia and Kadile (2017) looked at entrepreneurial potential in American homebrewers. They showed that selfefficacy mediated the relation between passion and entrepreneurial intent.

The process of starting an entrepreneurial endeavor may require the ability to overcome problems and challenges along the way, a competence displayed by individuals with high self-efficacy (Markman \& Baron, 2003). Therefore, entrepreneurial self-efficacy can be regarded as an influential factor in the relationship between entrepreneurial passion and entrepreneurial intent. We hypothesize:

- H5: Self-efficacy mediates the relationship between entrepreneurial passion and entrepreneurial intention.

\subsection{Effects of control variables on the structural model}

Previous studies have examined the effects of certain control variables on entrepreneurial intentions models in relation to differences in age (Hirschi, 2013), gender (Westhead \& Solesvik, 2016) type of graduation program (Maresch et al., 2016), students with entrepreneurial parents (Chlosta, Patzelt, Klein, \& Dormann, 2012), family support and/or family professional reference (Pruett, Shinnar, Toney, Llopis, \& Fox, 2009).

The possible factors affecting the conceptual model used, as shown in Figure 2.4.1, include variables such as age, gender, type of graduation 
program, graduation progress, entrepreneurial parents, professional reference, risk propensity and the family income. All these factors were analyzed.

The potential effect associated with risk propensity refers to an individual's wiliness to commit to an opportunity, knowing that there exists the possibility of failure (Sánchez \& Hernández-Sánchez, 2013). Thus, the type of question used in this research contemplated the approach of Rohrmann (2005), who points out that, in order to measure risk propensity, there are two main possibilities: 1. questions with risky options (gambling); and 2. statements that describe risk taking mind-sets. Only the first option was considered in the present study.

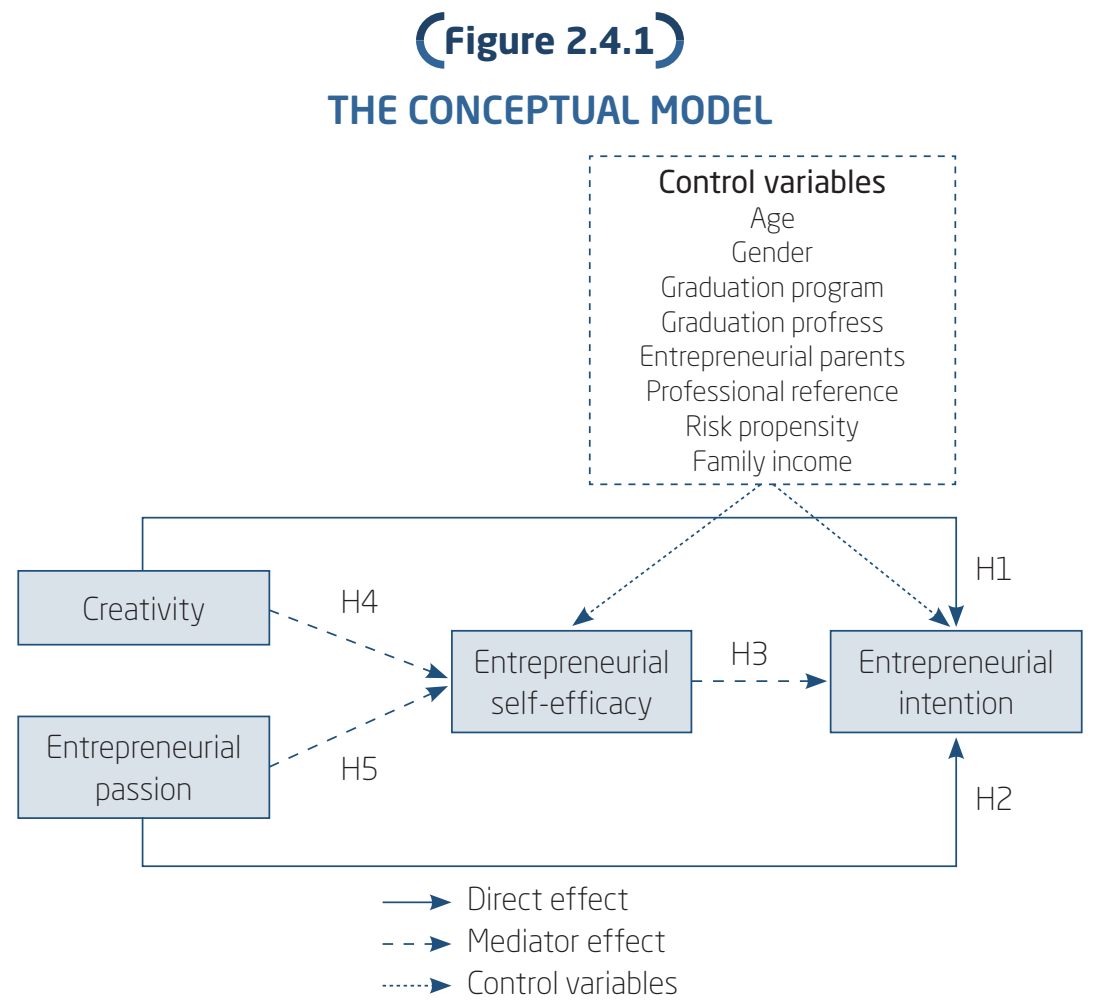

Source: Adapted from Biraglia and Kadile (2017)

\section{RESEARCH METHODOLOGY}

Several studies have used business, science, and engineering students as their target population, considering them as potential entrepreneurs (Liñán et al., 2011; Lüthje \& Franke, 2003). Hence, in this research, the students 
investigated were exclusively those coming from the School of Business Management and the School of Technology, following programs such as Information Systems, Software Engineering, Computer Engineering and Computer Science. Only students enrolled in the university were chosen to answer the research questionnaire. Moreover, no previous experience related to entrepreneurship was required.

Data were collected through a survey, a quantitative data collection method used to produce quantitative descriptions of some aspects of the population and to explain possible relationships between variables (Evans \& Rooney, 2013; Pinsonneault \& Kraemer, 1993). The data were collected in a cross-sectional manner and by a stratified and non-probability (purposive) sampling method (Vrontis \& Papasolomou, 2007). Stratification was made in order to have a sample that was representative of the population and the purposive method allowed choosing respondents of preordained wisdom. For this research, a division was made in relation to graduation progress, targeting students from the first and last years of the graduation program. Furthermore, the administration of these programs was contacted to seek permission and assistance with on-site data collection.

A total of 601 questionnaires were administered. A total of 102 questionnaires were from students from different programs than the ones being examined and, consequently, were removed. Additionally, 148 questionnaires had missing data and so they were discarded. Thus, 351 valid questionnaires were initially analyzed (a $58 \%$ response rate). Figure 3.1 shows the demographic characteristics, enabling us to visualize differences in the sample examined.

\section{(Figure 3.1)}

DEMOGRAPHIC PROFILE OF STUDENTS (N = 351)

\begin{tabular}{|c|c|c|c|}
\hline Dimensions & Category & Frequency & Percentage \\
\hline \multirow{2}{*}{ Gender } & Male & 263 & 74.9 \\
\hline & Female & 88 & 25.1 \\
\hline \multirow{2}{*}{ Age } & $17-23$ & 192 & 54.7 \\
\hline & Above 23 & 159 & 45.3 \\
\hline \multirow{2}{*}{ Marital status } & Single & 319 & 90.9 \\
\hline & Married & 32 & 9.1 \\
\hline
\end{tabular}




\section{(Figure 3.1 (conclusion))}

DEMOGRAPHIC PROFILE OF STUDENTS (N = 351)

\begin{tabular}{llll}
\hline \multicolumn{1}{c}{ Dimensions } & \multicolumn{1}{c}{ Category } & Frequency & Percentage \\
\hline \multirow{2}{*}{ Professional experience } & Freshman & 65 & 18.5 \\
\cline { 2 - 4 } & With job experience & 286 & 81.5 \\
\hline \multirow{2}{*}{ Graduation program } & School of Business Management & 179 & 51,0 \\
\cline { 2 - 4 } & School of Technology & 172 & 49.0 \\
\hline \multirow{2}{*}{ Graduation progress } & Novice & 189 & 53.8 \\
\cline { 2 - 4 } & Seniors & 162 & 46.2 \\
\hline \multirow{2}{*}{$\begin{array}{l}\text { Family income (monthly) } \\
\text { (in US\$) }\end{array}$} & US\$2,000 or less & 178 & 50.7 \\
\cline { 2 - 4 } & Above US\$ 2,000 & 173 & 49.3 \\
\hline
\end{tabular}

Source: Elaborated by the authors.

To address the research hypotheses and to attain the objectives of the study, we only adopted constructs from relevant literature from the field of entrepreneurship. The questionnaire was initially composed of two different sections containing 32 items using a seven-point Likert scale, with scores ranging from 1 (lowest measure) to 7 (highest measure). Section I referred to socio-demographic issues, considering the control variables (eight items) and Section II was related to the constructs of entrepreneurial intention (six items), entrepreneurial self-efficacy (seven items), entrepreneurial passion (five items) and creativity (six items). All items in Section II were used in a counterbalancing question to control for Common Method Bias, in accordance with Podsakoff, MacKenzie, Lee, and Podsakoff (2003). Additionally, the questionnaire was translated into the Portuguese language and submitted to an expert panel for review. The panel consisted of eight members: six experts in the field of entrepreneurship (five experts held PhDs and one expert was a $\mathrm{PhD}$ student), and two experts who were specialists in methodology and statistics, both with PhDs. All participants had at least five years of experience in their respective fields of expertise.

Subsequently, a pilot test was conducted among 82 students pursuing a bachelor's degree in Business Management. Due to validity and reliability issues, two items were eliminated from the initial questionnaire, one item from the entrepreneurial passion construct and one from the creativity construct. 
The structural equation modeling technique that was used was covariancebased, involving a maximum likelihood procedure and respecting data screening practices (Hair, Black, Babin, \& Anderson, 2009; Hair, Gabriel, \& Patel, 2014). In addition to identifying missing data, the presence of outliers was examined using the Mahalanobis distance $\left(\mathrm{D}^{2}\right)$, and 13 other questionnaires were eliminated in accordance with Byrne (2010) and Kline (2011). As a result, the sample size was reduced from 351 to 338 valid questionnaires. In accordance with Kline (2011), a ratio of at least 10 responses per parameter should be respected. Since the questionnaire comprised 24 items, this condition was met with the remaining sample size.

Another assumption necessary to perform structural equation modeling is the normal distribution of the data. Thus, the data were examined in relation to kurtosis, parameters suggested by Kline (2011), ranging from -10 to 10 , and skewness, parameters ranging from -3 to 3 , represent an acceptable normal distribution. The highest value observed regarding kurtosis was -1.24 and regarding the skewness parameter, it was -.68. Thus, the results indicated that non-normality was not a major issue.

The data collected were analyzed using the AMOS software (Analysis of Moment Structure), version 22, which operates using a technique based on the covariance structure modeling, and through the SPSS (Statistic Package for Social Science) software. The measurement model was tested regarding validity and reliability issues. The structural model was examined in relation to model fit and enabled the hypotheses to be tested (Hair et al., 2009).

\section{RESULTS}

Confirmatory factor analysis (CFA) was conducted in order to verify whether the predetermined sets of variables were interrelated in the hypothesized manner, testing standardized factor loadings (SFL) of 21 items related to four constructs, shown in Figure 4.1. The CFA results indicated an adequate model fit with the following indices: $\chi / \mathrm{df}=2.883$, CFI $=.933$, TLI $=$ .923 , RMSEA $=.075$. Individual item reliability was examined using item-total correlation. It was observed that one item from entrepreneurial passion (EPA3) showed an item-total correlation below the threshold limit of .5 (Hair et al., 2009), and was, therefore, eliminated.

The presence of common method bias was tested through Harman's one factor test and the common latent factor. The result indicated that a single factor was unable to explain a significant covariance, $48.46 \%$ being 
below the suggested value of $50 \%$. Additionally, a Common Latent Factor test was conducted by a confirmatory factor analysis using the AMOS software in accordance with Podsakoff et al. (2003). The creation of a latent variable (Common Latent Factor) gathers the common variance of all variables observed in the model. This variable was incorporated into the model and connected with all observed variables. The model was recalculated with adequate indices results $(\chi / \mathrm{df}=2.518, \mathrm{CFI}=.946, \mathrm{TLI}=.938 \mathrm{IFI}=.946$, RMSEA $=.067)$, suggesting a good fit. In addition, the relationship between the observable items and the latent variables did not lose statistical significance with the introduction of the common factor, and none of the paths (relations) with the common factor indicated statistical significance, suggesting that the presence of common method bias was not a problem for the present study.

Construct reliability was tested using composed reliability (CR) and Cronbach's Alpha ( $\alpha$ ). A score of .7 for CR and .7 for Cronbach's Alpha were considered adequate (Hair et al., 2009). In this study, the value for composed reliability ranged from .78 to .95 , whereas the Cronbach's Alpha ranged from .77 to .95 . To test for multi-collinearity issues, the maximum value of variance inflation (VIF) was examined, with all values obtained being below 10, as recommended by Hair et al. (2009). Therefore, all constructs and their dimensions showed adequate reliability, as shown in Figure 4.1.

(Figure 4.1)

MEASUREMENT MODEL

\begin{tabular}{lcccccc}
\hline Construct & Cronbach's alpha & SFL & SMC & $\begin{array}{c}\text { VIF } \\
\text { max.* }\end{array}$ & CR & AVE \\
\hline Entrepreneurial intention & .95 & & & & .95 & .76 \\
\hline EI1 & & .72 & .51 & 5.79 & & \\
\hline EI2 & .91 & .83 & 5.01 & & \\
\hline EI3 & .92 & .85 & 4.88 & & \\
\hline EI4 & .90 & .81 & 5.59 & & \\
\hline EI5 & .91 & .83 & 4.84 & & \\
\hline El6 & & .87 & .75 & 5.43 & & \\
\hline Entrepreneurial self-efficacy & .86 & & & & .88 & .51 \\
\hline ESE1 & & .61 & .37 & 5.81 & & \\
\hline
\end{tabular}




\section{(Figure 4.1 (conclusion))}

MEASUREMENT MODEL

\begin{tabular}{|c|c|c|c|c|c|c|}
\hline Construct & Cronbach's alpha & SFL & SMC & $\begin{array}{l}\text { VIF } \\
\text { max. }^{*}\end{array}$ & CR & AVE \\
\hline ESE2 & & .72 & .51 & 5.80 & & \\
\hline ESE3 & & .81 & .66 & 5.77 & & \\
\hline ESE4 & & .76 & .58 & 5.81 & & \\
\hline ESE5 & & .72 & .51 & 5.75 & & \\
\hline ESE6 & & .74 & .55 & 5.80 & & \\
\hline ESE7 & & .61 & .37 & 5.73 & & \\
\hline Entrepreneurial passion & .77 & & & & .78 & .76 \\
\hline EPAI & & .72 & .52 & 5.81 & & \\
\hline EPA2 & & .72 & .51 & 5.79 & & \\
\hline EPA4 & & .76 & .58 & 5.71 & & \\
\hline Creativity & .86 & & & & .88 & .60 \\
\hline CREI & & .64 & .41 & 5.81 & & \\
\hline CRE2 & & .74 & .54 & 5.79 & & \\
\hline CRE3 & & .78 & .61 & 5.81 & & \\
\hline CRE4 & & .86 & .74 & 5.80 & & \\
\hline CRE5 & & .84 & .70 & 5.81 & & \\
\hline
\end{tabular}

SFL: standardized factor loadings; SMC: squared multiple correlation; VIF max:: maximum variance inflation factor per item; CR: composed reliability; AVE: average variance extracted.

Source: Elaborated by the authors.

Convergent validity was tested through average variance extracted (AVE), with all constructs attaining values greater than .5 , as recommended by Hair et al. (2009). Discriminant validity was examined comparing AVE with the squared multiple correlations in order to check if the variance of construct items was related more closely to their own measures than to other constructs included in the study (Fornell \& Larcker, 1981). In this study, items ESE1, ESE2, ESE7, related to entrepreneurial self-efficacy, and EPA4, related to entrepreneurial passion, were eliminated due to discriminant validity issues, that is, their measures were too highly related to other constructs in 
the study. Figura 4.2 shows the final results for the discriminant validity test, in accordance with Fornell and Larcker (1981) and Koufteros (1999).

(Figure 4.2)

DISCRIMINANT VALIDITY

\begin{tabular}{ccccc}
\hline Construct & EI & ESE & EPA & CRE \\
\hline EI & .76 & & & \\
\hline ESE & .59 & .60 & & \\
\hline EPA & .20 & .36 & .60 & \\
\hline CRE & .41 & .43 & .34 & .60 \\
\hline
\end{tabular}

Diagonal elements (bold) are the average variance extracted (AVE). The off-diagonal elements are the squared multiple correlations. For discriminant validity, the diagonal elements (AVE) should be larger than the off-diagonal elements (squared multiple correlations). El: entrepreneurial intention; ESE: entrepreneurial self-efficacy; EPA: entrepreneurial passion; CRE: creativity.

Source: Elaborated by the authors.

After confirmatory factor analysis (CFA), the proposed structural model was examined by goodness of fit statistics, showing adequate indices results $(\chi / \mathrm{df}=2.231, \mathrm{CFI}=.967, \mathrm{TLI}=.961 \mathrm{IFI}=.968, \mathrm{RMSEA}=.060)$, suggesting a good fit, in accordance with Hair et al. (2009). The model explained $63 \%$ of the variance in the entrepreneurial intention and $50 \%$ of the variance in the entrepreneurial self-efficacy. The results are presented in Figure 4.3. Hypotheses 1, 2, 3 and 5 were supported. Hypothesis 4 was not supported.

\section{(Figure 4.3)}

RESULTS OF THE STRUCTURAL MODEL

\begin{tabular}{|c|c|c|c|c|}
\hline Hypothesis & & $\begin{array}{l}\text { Standardized } \\
\text { Estimate }\end{array}$ & t-value & Result \\
\hline $\mathrm{HI}$ & $\begin{array}{l}\text { Creativity -> entrepreneurial } \\
\text { intentions (mediated path) }\end{array}$ & .325 & $4.721^{\star \star \star}$ & $\begin{array}{l}\text { Supported (full } \\
\text { mediation) }\end{array}$ \\
\hline $\mathrm{H} 2$ & $\begin{array}{l}\text { Entrepreneurial passion -> } \\
\text { entrepreneurial intentions } \\
\text { (mediated path) }\end{array}$ & .469 & $5.716^{\star \star \star}$ & $\begin{array}{l}\text { Supported } \\
\text { (partial } \\
\text { mediation) }\end{array}$ \\
\hline $\mathrm{H3}$ & $\begin{array}{l}\text { Entrepreneurial self-efficacy } \rightarrow \\
\text { entrepreneurial intentions }\end{array}$ & .652 & $8.510^{\star \star \star}$ & Supported \\
\hline
\end{tabular}




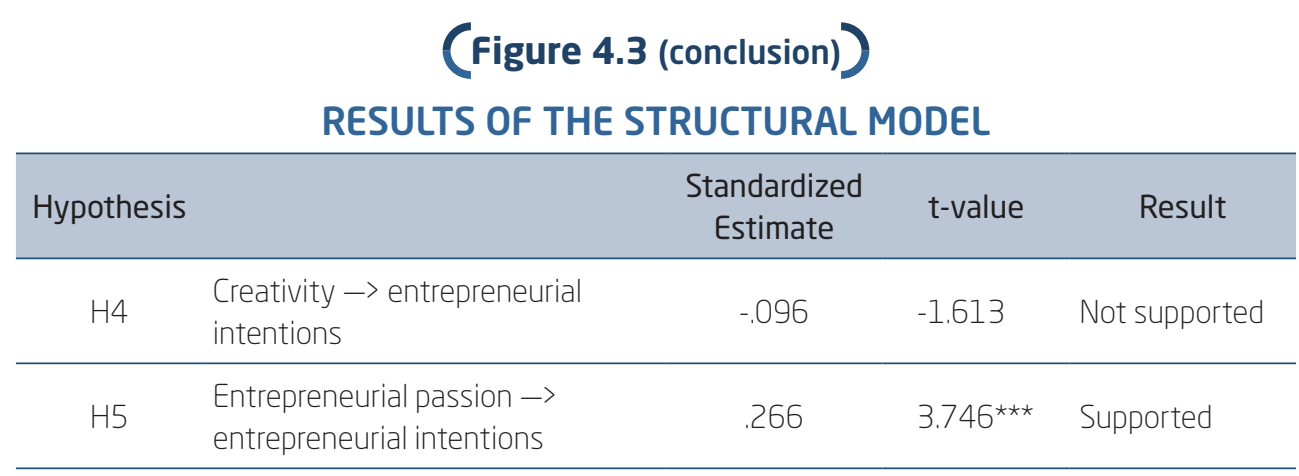

$\chi / \mathrm{df}=2.231 ; \mathrm{CFI}=.967 ; \mathrm{TLI}=.961 ; \mathrm{IFI}=.968 ; \mathrm{RMSEA}=.060 . \mathrm{R}^{2}$ (entrepreneurial intention) $=.63, \mathrm{R}^{2}$ (entrepreneurial self-efficacy) $=.50 .{ }^{\star \star \star} p<.001$

Source: Elaborated by the authors.

To test the mediating effect of entrepreneurial self-efficacy on entrepreneurial intention, the recommendations of Baron and Kenney (1986) were followed. As shown in Figure 4.4, results indicated a full mediation of entrepreneurial self-efficacy regarding creativity and entrepreneurial intentions and a partial mediation between entrepreneurial passion and entrepreneurial intentions, supporting hypotheses 1 and 2 .

\section{(Figure 4.4)}

MEDIATION ANALYSIS WITH BARON AND KENNY'S PROCEDURES

\begin{tabular}{cccccc}
\hline IV & $\begin{array}{c}\text { Effect on } \\
\text { mediator }\end{array}$ & $\begin{array}{c}\text { Effect of mediator } \\
\text { on DV }\end{array}$ & $\begin{array}{c}\text { Effect } \\
\text { on DV }\end{array}$ & $\begin{array}{c}\text { Effect on DV } \\
\text { with mediat. }\end{array}$ & $\begin{array}{c}\text { Mediation } \\
\text { result }\end{array}$ \\
\hline Passion & $0,66^{\star \star \star}$ & $.77^{\star \star \star}$ & $.64^{\star \star \star}$ & $.23^{\star \star \star}$ & Partial \\
\hline Creativity & $.59^{\star \star \star}$ & $.77^{\star \star \star}$ & $.45^{\star \star \star}$ & $-0,19$ & Full \\
\hline
\end{tabular}

IV: independent variable; DV: dependent variable; ${ }^{\star \star *} \mathrm{p}<.001$.

\section{Source: Elaborated by the authors.}

Despite Baron and Kenny (1986) being the most commonly used method for mediation, there exists a half dozen other methods and modeling tools that could be more suitable for testing such processes (Preacher \& Hayes, 2008). One such versatile modeling tool is PROCESS, which allows the integration of mediation and moderation analyses and bootstrapping methods (Hayes, 2012). In order to confirm the results obtained, PROCESS was used to verify the mediating effect (simple mediation effect: model 4 of PROCESS version 3.4 for SPSS) in the proposed model. As a result, and in accordance with the methodology proposed by Hayes (2012), creativity had an indirect 
effect, which was positive (0.6945) and statistically different from zero, as evidenced by a $95 \%$ bias-corrected bootstrap confidence interval that was entirely above zero (.5571 to .8410). Entrepreneurial passion also had a positive indirect effect (.2512) and a confidence interval above zero (.1342 to .3751). These results suggest the mediating effect of self-efficacy regarding entrepreneurial passion and creativity in relation to entrepreneurial intention.

The model was also examined in relation to eight control variables (age, gender, graduation program, graduation progress, professional reference, entrepreneurial parents, risk propensity and family income) in order to check for possible differences between groups. The chi-square difference test was used, in accordance with Cohen (1992), as shown in Figure 4.5. Noticeably, there seems to be no significant differences in relation to age, gender, type of graduation program, the influence of entrepreneurial parents, professional reference and family income. On the other hand, it seems that there are differences regarding the graduation progress among students in the path of creativity and self-efficacy. This suggests that, at the beginning of the program, students who think of themselves as creative, tend to have greater self-efficacy than senior students. This may occur because senior students, having more maturity and academic knowledge, understand that creativity alone may not be enough to ensure entrepreneurial success and are therefore less affected by the perception of creativity. In addition, the complete structural model also suggested significant differences in regard to risk propensity, indicating, unsurprisingly, a distinction between students with high risk propensity and those with low risk propensity.

(Figure 4.5)

EFFECTS OF CONTROL VARIABLES ON THE STRUCTURAL MODEL

\begin{tabular}{lccccccccc}
\hline \multicolumn{1}{c}{ Paths } & Age & Gender & $\begin{array}{c}\text { Grad. } \\
\text { school }\end{array}$ & $\begin{array}{c}\text { Grad. } \\
\text { progr. }\end{array}$ & $\begin{array}{c}\text { Entrep. } \\
\text { parents }\end{array}$ & $\begin{array}{c}\text { Prof. } \\
\text { ref. }\end{array}$ & $\begin{array}{c}\text { Risk } \\
\text { prop. }\end{array}$ & $\begin{array}{c}\text { Family } \\
\text { income }\end{array}$ \\
\hline Structural model & .660 & .527 & .627 & .664 & .665 & .690 & $.037^{* *}$ & .699 \\
\hline $\begin{array}{l}\text { Creativity } \rightarrow \text { entrepreneurial } \\
\text { self-efficacy }\end{array}$ & .139 & .543 & .448 & $.060^{*}$ & .959 & .332 & .965 & .495 \\
\hline $\begin{array}{l}\text { Entrepreneurial self-efficacy } \\
->\text { entrepreneurial intentions }\end{array}$ & .342 & .147 & .126 & .196 & .798 & .934 & .178 & .458 \\
\hline $\begin{array}{l}\text { Entrepreneurial passion } \rightarrow \\
\text { entrepreneurial intentions }\end{array}$ & .899 & .772 & .546 & .158 & .477 & .147 & .793 & .287 \\
\hline
\end{tabular}




\section{(Figure 4.5 (conclusion))}

EFFECTS OF CONTROL VARIABLES ON THE STRUCTURAL MODEL

\begin{tabular}{ccccccccc}
\hline \multicolumn{10}{c}{ Paths } & Age & Gender & $\begin{array}{c}\text { Grad. } \\
\text { school }\end{array}$ & $\begin{array}{c}\text { Grad. } \\
\text { progr. }\end{array}$ & $\begin{array}{c}\text { Entrep. } \\
\text { parents }\end{array}$ & $\begin{array}{c}\text { Prof. } \\
\text { ref. }\end{array}$ & $\begin{array}{c}\text { Risk } \\
\text { prop. }\end{array}$ & $\begin{array}{c}\text { Family } \\
\text { income }\end{array}$ \\
\hline $\begin{array}{l}\text { Entrepreneurial Passion } \rightarrow \\
\text { entrepreneurial self-efficacy }\end{array}$ & .839 & .316 & .774 & .161 & .803 & .883 & .961 & .465 \\
\hline
\end{tabular}

${ }^{\star} p<.05,{ }^{* \star *} \mathrm{p}<.01 .{ }^{* \star \star} \mathrm{p}<.001$.

\section{DISCUSSION}

This study adds to the existing literature on antecedents of entrepreneurial intentions based upon the framework of SCT (Bandura, 1986, 1999). In line with the visible growth of research interest into the reasons why individuals pursue an entrepreneurial venture (Lüthje \& Franke, 2003; Zhao et al., 2005), this study examines the influence of entrepreneurial passion and creativity as antecedents of entrepreneurial intentions in Brazil.

The results indicate a direct and an indirect effect of entrepreneurial passion on entrepreneurial intentions. Support for hypotheses H2 and H5 is evidence of this. Therefore, the results support the idea that entrepreneurial passion may play a role in inventing and getting individuals involved with the intention of beginning an entrepreneurial venture (Biraglia \& Kadile, 2017; Cardon et al., 2009). With regard to creativity, since hypothesis H4 was not supported, the results did not show a direct correlation between creativity and entrepreneurial intent. This result supports the findings of Bellò et al. (2018), which suggest that individuals, apart from perceiving themselves as creative, need to feel capable of performing entrepreneurial activities, that is, they need self-efficacy. In fact, this study showed that creativity is fully mediated by entrepreneurial self-efficacy in regard to entrepreneurial intentions, hypothesis $\mathrm{H} 1$. As such, the perception of being creative may only have an influence on the entrepreneurial intent in individuals that have self-efficacy (Bellò et al., 2018; Biraglia \& Kadile, 2017). Additionally, this study confirms the importance of self-efficacy in relation to entrepreneurial intentions (Chen et al., 1998; Zhao et al., 2005), as hypotheses H1, $\mathrm{H} 2$ and $\mathrm{H} 3$ were supported. 
The structural model was able to explain $63 \%$ of the variance in entrepreneurial intention $(\mathrm{R} 2=.63)$ which indicates the explanatory power of entrepreneurial intention. Entrepreneurial intention models, such as Ajzen's Theory of Planned Behavior (1991) and Shapero and Sokol's model of the Entrepreneurial Event (1982), indicate an average predictive power of 35\% and $41 \%$, respectively (Armitage \& Conner, 2001). Compared to models that also used the perspective of Bandura's SCT (1986) and investigated the effects of other cognitive and personal variables in entrepreneurial intent, the model validated in the present study showed superior values with regard to the explanatory power of entrepreneurial intention. For example, Zhao et al. (2005) showed a predictive power of $42 \%$ of the variance in entrepreneurial intention; Sánchez (2012) found a value of 39\%; Bacq et al. (2017) obtained 35\% and Bellò et al. (2018) obtained 25\%.

The relationships and paths examined in the structural model did not show significant differences with age, gender, graduation program, entrepreneurial parents, professional reference or family income. This may have been due to the specific cultural context in which the survey took place and the similar background of the students considered. These results are also in line with studies that did not find significant differences in entrepreneurial intention with regard to gender (Gupta, Turban, Wasti, \& Sikdar, 2009), entrepreneurial parents (Zapkau, Schwens, Steinmetz, \& Kabst, 2015) and family support and/or professional reference (Turker \& Sonmez Selcuk, 2009).

Investigating differences in relation to graduation progress, a possible distinction appeared between the students examined on the creativity and the self-efficacy path of the structural model. Novice students, who consider themselves creative, tend to have a stronger relationship with self-efficacy than senior students. In the sample examined, as the students progressed through their graduation program, the relationship between creativity and self-efficacy tended to decrease. Thus, the perception of being creative does not impact so much on the personal confidence to perform tasks and roles related to entrepreneurship for senior students. This may be related to the fact that senior students tend to be more mature and have more understanding than novice students in relation to the complex decision-making process of starting an entrepreneurial career (Hirschi, 2013). In addition, the model also indicated a possible difference concerning risk propensity among students. This supports existing literature demonstrating that entrepreneurial intention can depend on individual-level factors, such as risktaking propensity (Saeed, Muffatto, \& Yousafzai, 2014). 


\section{CONCLUSION}

The results indicate that entrepreneurial passion shows a direct and an indirect relationship (through self-efficacy) with entrepreneurial intention. Creativity, on the other hand, is not directly related to entrepreneurial intention, but shows an indirect relationship with entrepreneurial intent through self-efficacy. Thus, even in a Brazilian context, known for its creative aspect related to the "jeitinho brasileiro", creativity alone may not be sufficient in determining individual entrepreneurial intent.

\subsection{Implications}

This study offers some contributions to the theoretical field of entrepreneurship research. First, the validated model, which takes into account the perspective of the Social Cognitive Theory, provided support for the influence of creativity and entrepreneurial passion in entrepreneurial intention in Brazil. Secondly, the study indicated that the relationship between creativity and entrepreneurial intention is not a direct relationship and other mediating and/or moderating variables must be considered (Bellò et al., 2017; Biraglia $\&$ Kadile, 2017). Third, this study reinforces the importance of self-efficacy in the study of cognitive and personal variables (Zhao et al., 2005). Finally, this work contributes to the field of entrepreneurship by supporting the importance of emotional factors, such as entrepreneurial passion, to the study of entrepreneurial intention and action (Cardon et al., 2013).

From a practitioner's point of view, this work has other contributions. According to Social Cognitive Theory, the environment may influence individual behavior. Therefore, universities and other educational institutions should strengthen and promote an entrepreneurial environment. In Brazil, in particular, there are indications that universities are disconnected from the labor market and do not encourage students to pursue their entrepreneurial dreams (Sebrae, 2016). Therefore, the universities should stimulate the interaction between students and entrepreneurs in a way that facilitates the exchange of information, motivations, experiences and strategies related to starting an entrepreneurial venture, possibly increasing students' selfefficacy and enterprising passion. Additionally, specific courses, workshops and lectures could focus on increasing students' self-efficacy, as well as awakening and inspiring a passion to undertake entrepreneurial activities. Finally, the instrument and model used in this study could be a first step 
towards identifying people with a certain degree of entrepreneurial passion, perception of being creative, entrepreneurial self-efficacy and entrepreneurial intent. This could be useful to select candidates for incubators and start-ups.

\subsection{Limitations and future research}

This study contains some limitations and some insight for future research. First, a non-probabilistic sample of students from only one university was used. Consequently, the results represented a specific context, making it difficult to generalize the findings to other scenarios. Another limitation concerns the type of questions used in the instrument, in which the answers obtained were products of the respondent's self-assessment perception. This is the case for the creativity construct in which the measurement was an individual's perception of being creative and not their actual creative ability. Moreover, it is important to point out that the statistical technique used in this study does not allow us to affirm causal relationships, but rather correlations. This means that this study cannot determine what causes a student's entrepreneurial intentions, but can only suggest factors that may influence their entrepreneurial intent.

A further limitation issue is related to the use of cross-sectional studies that embody the implicit assumption that model parameters are stable across firms and over time (Bowen \& Wiersema, 1999). Cross-sectional approaches to mediation may generate biased estimates of longitudinal parameters. This may mean that a variable found to be a strong mediator in a cross-sectional analysis may not be a substantial mediator in a longitudinal analysis (Maxwell, Cole, \& Mitchell, 2011).

Another important limitation concerns the translated instrument which, even after being analyzed by a panel of specialists and pre-tested in a pilot study, may have caused interpretation problems for the respondents. In addition, understanding the issues and context in the English language may have caused modifications when translated into the Portuguese and Brazilian contexts. As a possible consequence, it was observed that all the constructs investigated, with the exception of entrepreneurial intention, had items excluded from the measured instrument by the statistical criteria established in the academic literature.

To enable comparative studies, future research could replicate the model used in this study at other universities in South America and elsewhere. In addition, adaptations and modifications to the structural model used here could be investigated, for example, to analyze whether entrepreneurial 
passion (or entrepreneurial self-efficacy) exerts a moderator effect on the entrepreneurial intentions of university students.

\section{A INFLUÊNCIA DA PAIXÃO EMPREENDEDORA E DA CRIATIVIDADE NAS INTENÇÕES EMPREENDEDORAS}

\section{RESUMO}

Objetivo: Este estudo visa analisar a influência da paixão empreendedora e da criatividade na intenção empreendedora e o papel mediador da autoeficácia empreendedora entre as variáveis pessoais/cognitivas e a intenção empreendedora.

Originalidade/valor: Ressaltando a importância das variáveis cognitivas e emocionais que podem influenciar as intenções empreendedoras dos estudantes universitários, tais como a criatividade e a paixão empreendedora, este estudo mostra o importante papel das universidades no desenvolvimento das intenções empreendedoras. De acordo com a Teoria Social Cognitiva (TSC), o ambiente influencia o comportamento do indivíduo, as universidades deveriam promover um ambiente empreendedor, possibilitando a criação de novos empregos e empresas.

Design/metodologia/abordagem: Os dados foram coletados por uma pesquisa feita com estudantes de Administração e de Informática de uma universidade brasileira. Ao todo, foram obtidas 338 respostas válidas, analisadas por meio de modelagem de equações estruturais. Essa coleta foi realizada de maneira transversal e com um método de amostragem não-probabilística. Para investigar as hipóteses e atingir os objetivos deste estudo, todos os conceitos foram adaptados a partir da literatura da área de empreendedorismo. O modelo estrutural foi avaliado em relação ao seu ajuste, permitindo a testagem de hipóteses.

Resultados: Os resultados mostraram uma relação positiva direta e indireta entre a paixão empreendedora e a intenção de empreender. A respeito da criatividade, foi possível perceber apenas uma influência indireta desse fator na intenção empreendedora, sendo essa relação mediada por meio da autoeficácia empreendedora. Não foram encontradas diferenças significantes no modelo com relação a idade, gênero, curso de graduação, histórico empreendedor familiar, modelo de comportamento e a renda familiar. 


\section{PALAVRAS-CHAVE}

Intenção empreendedora. Teoria Social Cognitiva. Criatividade. Paixão empreendedora. Autoeficácia.

\section{REFERENCES}

Ajzen, I. (1991). The Theory of Planned Behavior. Organizational Behavior and Human Decision Processes, 50(2), 179-211. https://doi.org/10.1016/07495978(91)90020-T

Amabile, T. (1997). Entrepreneurial creativity through motivational synergy. The Journal of Creative Behavior, 31 (1), 18-26. https://doi.org/10.1002/j. 2162-6057.1997.tb00778.x

Armitage, C. J., \& Conner, M. (2001). Efficacy of the Theory of Planned Behaviour: A meta-analytic review. The British Journal of Social Psychology, 40(4), 471-499. https://doi.org/10.1348/014466601164939

Bacq, S., Ofstein, L. F., Kickul, J. R., \& Gundry, L. K. (2017). Perceived entrepreneurial munificence and entrepreneurial intentions: A social cognitive perspective. International Small Business Journal, 35(5), 639-659. https:// doi.org/10.1177/0266242616658943

Bandura, A. (1986). Social foundations of thought and action: A social cognitive theory. Englewood, New Jersey: Prentice Hall.

Bandura, A. (1993). Perceived self-Efficacy in cognitive development and functioning. Educational Psychologist, 28(2), 117-148. https://doi.org/10. 1207/s15326985ep2802

Bandura, A. (1999). Social Cognitive Theory : An agentic perspective. Asian Journal of Social Psychology, 2(1), 21-41. https://doi.org/10.1111/1467839X.00024

Baron, R. A. (2007). Behavioral and cognitive factors in entrepreneurship: Entrepreneurs as the active element in new venture creation. Strategic Entrepreneurship Journal, 1 (1-2), 167-182.

Baron, R., \& Kenny, D. (1986). The moderator-mediator variable distinction in social psychological research. Journal of Personality and Social Psychology, 51 (6), 1173-1182. https://doi.org/10.1037/0022-3514.51.6.1173 
Bellò, B., Mattana, V., \& Loi, M. (2018). The power of peers: A new look at the impact of creativity, entrepreneurial intentions. International Journal of Entrepreneurial Behavior \& Research, 24(1), 214-233. https://doi.org/10. 1108/IJEBR-07-2016-0205

Biraglia, A., \& Kadile, V. (2017). The role of entrepreneurial passion and creativity in developing entrepreneurial intentions: Insights from American homebrewers. Journal of Small Business Management, 55(1), 170-188. https://doi.org/10.1111/jsbm.12242

Bird, B. (1988). Implementing entrepreneurial ideas: The case for intention. The Academy of Management Review, 13(3), 442-453. https://doi.org/10. 5465/AMR.1988.4306970

Bowen, H. P., \& Wiersema, M. F. (1999). Matching method to paradigm in strategy research: Limitations of cross-sectional analysis and some methodological alternatives. Strategic Management Journal, 20(7), 625-636. https://doi.org/10.1002/(sici) 1097-0266(199907)20:7<625::aid-smj45> 3.3.co;2-m

Boyd, N. G., \& Vozikis, G. S. (1994). The influence of self-efficacy on the development of entrepreneurial intentions and actions. Entrepreneurship Theory and Practice, 18, 63-77. https://doi.org/10.1080/026404101524 75847

Bruton, G. D., Ahlstrom, D., \& Obloj, K. (2008). Entrepreneurship in emerging economies: The research go in the future. Entrepreneurship Theory and Practice, 32 (January), 1-14. https://doi.org/10.1111/j.1540-6520. 2007.00213.x

Byrne, B. M. (2010). Structural equation modeling with AMOS. In: Structural Equation Modeling. (2. ed.). New York: Routledge.

Cardon, M. S., Gregoire, D. A., Stevens, C. E., \& Patel, P. C. (2013). Measuring entrepreneurial passion: Conceptual foundations and scale validation. Journal of Business Venturing, 28(3), 373-396. https://doi.org/10.1016/j. jbusvent.2012.03.003

Cardon, M. S., Wincent, J., Singh, J., \& Drnovsek, M. (2009). The nature and experience of entrepreneurial passion. Academy of Management Review, 34(3), 511-532. https://doi.org/10.5465/AMR.2009.40633190

Cardon, M. S., Zietsma, C., Saparito, P., Matherne, B. P., \& Davis, C. (2005). A tale of passion: New insights into entrepreneurship from a parenthood metaphor. Journal of Business Venturing, 20(1), 23-45. https://doi.org/ 10.1016/j.jbusvent.2004.01.002 
Chen, C., Greene, P. P. G., \& Crick, A. (1998). Does entrepreneurial self-efficacy distinguish entrepreneurs from managers? Journal of Business Venturing, 13(4), 295-316. https://doi.org/10.1016/S0883-9026(97)00029-3

Chlosta, S., Patzelt, H., Klein, S. B., \& Dormann, C. (2012). Parental role models and the decision to become self-employed: The moderating effect of personality. Small Business Economics, 38(1), 121-138.

Cohen, J. (1992). A power primer. Psychological Bulletin, 112(1), 155-159. https://doi.org/10.1037/0033-2909.112.1.155

Davidsson, P. (1995). Determinants of entrepreneurial intentions. RENT IX Workshop, 1-31. https://doi.org/10.1016/S1053-5357(01)00101-9

Dimov, D. (2007). Beyond the single-person, single-insight attribution in understanding entrepreneurial opportunities. Entrepreneurship \& Regional Development, 31(5), 713-731.

Dunn, C. (2014). African-Brazilian culture and regional identity in Bahia, Brazil. Hispanic American Historical Review, 94(3), 522-524.

Evans, A. N., \& Rooney, B. J. (2013). Methods in psychological research (3rd ed.). Thousand Oaks, CA: SAGE Publications.

Feldman, D. C., \& Bolino, M. C. (2000). Career patterns of the self-employed: Career motivations and career outcomes. Journal of Small Business Management, 38(3), 53-67.

Fleith, D. S. (2011). Creativity in the Brazilian culture. Online Reading in Psychology and Culture, 4(3), 1-20.

Fornell, C., \& Larcker, D. F. (1981). Evaluating structural equation models with unobservable variables and measurement error. Journal of Marketing Research, 18(1), 39. https://doi.org/10.2307/3151312

Gelderen, M. Van, Brand, M., Praag, M. Van, Bodewes, W., Poutsma, E., \& Gils, A. Van. (2008). Explaining entrepreneurial intentions by means of the theory of planned behaviour. Career Development International, 13(6), 538-559. https://doi.org/10.1108/13620430810901688

Gupta, V. K., Turban, D. B., Wasti, S. A., \& Sikdar, A. (2009). The role of gender stereotypes in perceptions of entrepreneurs and intentions to become an entrepreneur. Entrepreneurship Theory and Practice, 33 (2), 397-417. https://doi.org/10.1111/j.1540-6520.2007.00179.x

Hair, J. F., Black, W. C., Babin, B., \& Anderson, R. E. (2009). Multivariate data analysis $\left(7^{\circ}\right)$. Upper Saddle River, NJ: Prentice Hall.

Hair, J. F., Gabriel, M. L. D. S., \& Patel, V. K. (2014). AMOS CovarianceBased Structural Equation Modeling (CB-SEM): Guidelines on its applica- 
tion as a marketing research tool. Revista Brasileira de Marketing, 13(02), 44-55. https://doi.org/10.5585/remark.v13i2.2718

Hayes, A. F. (2012). PROCESS: A versatile computational tool for observed variable mediation, moderation, and conditional process modeling. White Paper, 1-39. https://doi.org/978-1-60918-230-4

Hills, G. E., Shrader, R. C., \& Lumpkin, G. T. (1999). Opportunity recognition as a creative process. Frontiers of Entrepreneurship Research, 19(19), 216-227. Retrieved from http://scholar.google.com/scholar?hl=en\&btnG $=$ Search\&q=intitle:Opportunity + recognition + as $+a+$ creative + process $\# 0$

Hirschi, A. (2013). Career decision making, stability, and actualization of career intentions: The case of entrepreneurial intentions. Journal of Career Assessment, 21 (4), 555-571. https://doi.org/10.1177/1069072712475287

Kline, R. B. (2011). Principles and practice of structural equation modeling (3. ed.). New York: The Guilford Press.

Koufteros, X. (1999). Testing a model of pull production: A paradigm for manufacturing research using structural equation modeling. Journal of Operations Management, 17(4), 467-488. https://doi.org/10.1016/S02726963(99)00002-9

Krueger, N. F., \& Day, M. (2010). Looking forward, looking backward: From entrepreneurial cognition to neuroentrepreneurship. In Handbook of Entrepreneurship Research (pp. p.321-358). https://doi.org/10.1007/978-1-44191191-9

Krueger, N. F., Reilly, M. D., \& Carsrud, A. (2000). Competing models of entrepreneurial intentions. Journal of Business Venturing, 15(5-6), 411-432. https://doi.org/http://dx.doi.org/10.1016/S0883-9026(98)00033-0

Lee, S. H., \& Wong, P. K. (2004). An exploratory study of technopreneurial intentions: A career anchor perspective. Journal of Business Venturing, 19(1), 7-28. https://doi.org/10.1016/S0883-9026(02)00112-X

Lee, S. Y., Florida, R., \& Acs, Z. J. (2004). Creativity and entrepreneurship: A regional analysis of new firm formation. Regional Studies, 38(8), 879-891. https://doi.org/10.1080/0034340042000280910

Liguori, E. W., Bendickson, J. S., \& McDowell, W. C. (2018). Revisiting entrepreneurial intentions: A social cognitive career theory approach. International Entrepreneurship and Management Journal, 14(1), 67-78. https:// doi.org/10.1007/s11365-017-0462-7

Liñán, F., \& Chen, Y.-W. W. (2009). Development and cross-cultural application of a specific instrument to measure entrepreneurial intentions. Entre- 
preneurship: Theory and Practice, 33(3), 593-617. https://doi.org/10.1111/j. 1540-6520.2009.00318.x

Liñán, F., \& Fayolle, A. (2015). A systematic literature review on entrepreneurial intentions: Citation, thematic analyses, and research agenda. International Entrepreneurship and Management Journal, 11(4), 907-933. https://doi.org/10.1007/s11365-015-0356-5

Liñán, F., Urbano, D., \& Guerrero, M. (2011). Regional variations in entrepreneurial cognitions: Start-up intentions of university students in Spain. Entrepreneurship \& Regional Development, 23(3-4), 187-215. https://doi. org/10.1080/08985620903233929

Lüthje, C., \& Franke, N. (2003). The 'making' of an entrepreneur: Testing a model of entrepreneurial intent among engineering students at MIT. R\&D Management, 33(2), 135-147. https://doi.org/10.1111/1467-9310.00288

Maresch, D., Harms, R., Kailer, N., \& Wimmer-Wurm, B. (2016). The impact of entrepreneurship education on the entrepreneurial intention of students in Science and Engineering versus business studies university programs. Technological Forecasting and Social Change, 104, 172-179. https://doi.org/ 10.1016/j.techfore.2015.11.006

Markman, G. D., \& Baron, R. A. (2003). Person-entrepreneurship fit: Why some people are more successful as entrepreneurs than others. Human Resource Management Review, 13(2), 281-301. https://doi.org/10.1016/ S1053-4822(03)00018-4

Maxwell, S. E., Cole, D. A., \& Mitchell, M. A. (2011). Bias in cross-sectional analyses of longitudinal mediation: Partial and complete mediation under an autoregressive model. Multivariate Behavioral Research, 46(5), 816-841. https://doi.org/10.1080/00273171.2011.606716

McGee, J. E., Peterson, M., Mueller, S. L., \& Sequeira, J. M. (2009). Entrepreneurial self-efficacy: Refining the measure. Entrepreneurship: Theory and Practice, 33(4), 965-988. https://doi.org/10.1111/j.1540-6520.2009.00304.x

Miao, C., Qian, S., \& Ma, D. (2016). The relationship between entrepreneurial self-efficacy and firm performance: A meta-analysis of main and moderator effects. Journal of Small Business Management, 55(1), 87-107. https://doi.org/10.1111/jsbm.12240

Murnieks, C. Y., Mosakowski, E., \& Cardon, M. S. (2012). Pathways of passion: Identity centrality, passion and behavior among entrepreneurs. Journal of Management, 40(6), 1583-1606. https://doi.org/10.1177/0149206311 433855 
Nabi, G., Walmsley, A., \& Holden, R. (2015). Pushed or pulled? Exploring the factors underpinning graduate start-ups and non-start-ups. Journal of Education and Work, 28(5), 481-506. https://doi.org/10.1080/13639080.2 013.805189

Pinsonneault, A., \& Kraemer, K. L. (1993). Survey research methodology in Management Information Systems: An assessment. Management Information Systems, 10(2), 75-105. https://doi.org/1175042

Podsakoff, P. M., MacKenzie, S. B., Lee, J. Y., \& Podsakoff, N. P. (2003). Common method biases in behavioral research: A critical review of the literature and recommended remedies. Journal of Applied Psychology, 88(5), 879-903. https://doi.org/10.1037/0021-9010.88.5.879

Preacher, K. J., \& Hayes, A. F. (2008). Asymptotic and resampling strategies for assessing and comparing indirect effects in multiple mediator models. Behavior Research Methods, 40(3), 879-891. https://doi.org/10.3758/ BRM.40.3.879

Pruett, M., Shinnar, R., Toney, B., Llopis, F., \& Fox, J. (2009). Explaining entrepreneurial intentions of university students: A cross-cultural study. International Journal of Entrepreneurial Behavior \& Research, 15(6), 571-594. https://doi.org/10.1108/13552550910995443

Rauch, A., \& Hulsink, W. (2015). Putting entrepreneurship education where the intention to act lies: An investigation into the impact of entrepreneurship education on entrepreneurial behavior. Academy of Management Learning and Education, 14(2), 187-204. https://doi.org/10.5465/amle.2012.0293

Rodrigues, R., Milfont, T., Ferreira, M., Porto, J. B., \& Fischer, R. (2011). Brazilian jeitinho: Understanding and explaining an indigenous psychological construct. Interamerican Journal of Psychology, 45(1989), 29-38. Retrieved from http://www.psicorip.org/Resumos/PerP/RIP/RIP041a5/ RIP04505.pdf

Rohrmann, B. (2005). Risk Attitude Scales : Concepts , questionnaires , utilizations. University of Melbourne, (January), 21.

Roy, R., Akhtar, F., \& Das, N. (2017). Entrepreneurial intention among science \& technology students in India: Extending the theory of planned behavior. International Entrepreneurship and Management Journal, 13(4), 1013-1041. https://doi.org/10.1007/s11365-017-0434-y

Saeed, S., Muffatto, M., \& Yousafzai, S. (2014). A multi-level study of entrepreneurship education among Pakistani university students. Entrepreneurship Research Journal, 4(3), 297-321. https://doi.org/10.1515/erj-2013-0041 
Sánchez, J. C. (2012). Entrepreneurial intentions: The role of the cognitive variables. Entrepreneurship: Born, Made and Educated, 27-50. Retrieved from http://cdn.intechopen.com/pdfs/31832.pdf

Sánchez, J. C., \& Hernández-Sánchez, B. R. (2013). Gender, personal traits, and entrepreneurial intentions. Business and Management Research, 3(1), 31-40. https://doi.org/10.5430/bmr.v3n1p31

Serviço Brasileiro de Apoio às Micro e Pequenas Empresas - Sebrae. (2014). Participação das micro e pequenas empresas na economia brasileira. Brasília: Sebrae. Shapero, A., \& Sokol, L. (1982). The social dimensions of entrepreneurship. In Encyclopedia of Entrepreneurship (pp. 72-90). University of Illinois at Urbana-Champaign's Academy for Entrepreneurial Leadership Historical Research Reference in Entrepreneurship.

Souitaris, V., Zerbinati, S., \& Al-Laham, A. (2007). Do entrepreneurship programmes raise entrepreneurial intention of science and engineering students? The effect of learning, inspiration and resources. Journal of Business Venturing, 22(4), 566-591. https://doi.org/10.1016/j.jbusvent. 2006.05.002

Stenholm, P., \& Renko, M. (2016). Passionate bricoleurs and new venture survival. Journal of Business Venturing, 31(5), 595-611. https://doi.org/ 10.1016/j.jbusvent.2016.05.004

Thorgren, S., \& Wincent, J. (2015). Passion and habitual entrepreneurship. International Small Business Journal, 33(2), 216-227. https://doi.org/10. $1177 / 0266242613487085$

Tsai, K. H., Chang, H. C., \& Peng, C. Y. (2016). Extending the link between entrepreneurial self-efficacy and intention: A moderated mediation model. International Entrepreneurship and Management Journal, 12(2), 445-463. https://doi.org/10.1007/s11365-014-0351-2

Turker, D., \& Sonmez Selcuk, S. (2009). Which factors affect entrepreneurial intention of university students? Journal of European Industrial Training, 33(2), 142-159. https://doi.org/10.1108/03090590910939049

Vrontis, D., \& Papasolomou, I. (2007). Brand and product building: the case of the Cyprus wine industry. Journal of Product \& Brand Management, 16(3), 159-167. https://doi.org/10.1108/10610420710751537

Ward, T. B. (2004). Cognition, creativity, and entrepreneurship. Journal of Business Venturing, 19(2), 173-188. https://doi.org/10.1016/S0883-9026 (03)00005-3 
West, G. P., Bamford, C. E., \& Marsden, J. W. (2008). Constraining entrepreneurial economic development in emerging Latin American economies: Application and extensions of resource based theor. Entrepreneurship Theory and Practice, 32(1), 15-37. https://doi.org/10.1111/j.1540-6520.2010. 00396.x

Westhead, P., \& Solesvik, M. Z. (2016). Entrepreneurship education and entrepreneurial intention: Do female students benefit? International Small Business Journal, 34(8), 979-1003. https://doi.org/10.1177/0266242 615612534

Wood, R., \& Bandura, A. (1989). Social Cognitive Theory of Organizational Management. Academy of Management, 14(3), 361-384.

Zampetakis, L. A., Gotsi, M., Andriopoulos, C., \& Moustakis, V. (2011). Creativity and entrepreneurial intention in young people Empirical insights from business school students. The International Journal of Entrepreneurship and Innovation, 12 (3), 189-199. https://doi.org/10.5367/ijei.2011.0037

Zampetakis, L. A., \& Moustakis, V. (2006). Linking creativity with entrepreneurial intentions: A structural approach. International Entrepreneurship and Management Journal, 2(3), 413-428. https://doi.org/10.1007/s11365-0060006-z

Zapkau, F. B., Schwens, C., Steinmetz, H., \& Kabst, R. (2015). Disentangling the effect of prior entrepreneurial exposure on entrepreneurial intention. Journal of Business Research, 68(3), 639-653. https://doi.org/10.1016/j. jbusres.2014.08.007

Zhao, H., Seibert, S., \& Hills, G. (2005). The mediating role of self-efficacy in the development of entrepreneurial intentions. Journal of Applied Psychology, 90(6), 1265-1272. https://doi.org/10.1037/0021-9010.90.6.1265

\section{AUTHOR NOTES}

Bernardo Bignetti, master from the Graduate Program in Administration, Pontifical Catholic University of Rio Grande do Sul (PUCRS); Ana C. M. Z. Santos, PhD from the Graduate Program in Administration, University of Rio dos Sinos Valley (Unisinos); Peter B. Hansen, $\mathrm{PhD}$ from the Production and Transport Engineering Department (Deprot), Federal University of Rio Grande do Sul (UFRGS); Eder Henriqson, PhD from the Production and Transport Engineering Department, UFRGS.

Bernardo Bignetti is now PhD student at the Graduate Program in Administration of PUCRS; Ana C. M. Z. Santos is now professor at the Graduate Program in Administration of PUCRS; Peter B. Hansen is now post doctoral researcher at the Deprot-UFRGS; Eder Henriqson is now professor at the Graduate Program in Administration of PUCRS. 
Correspondence concerning this article should be addressed to Bernardo Bignetti, Avenida Ipiranga, 6681, Prédio 50, Partenon, Porto Alegre, Rio Grande do Sul, Brazil, CEP 90619-900. E-mail: bernardobignetti@hotmail.com

EDITORIAL BOARD

Editor-in-chief

Gilberto Perez

\section{Associated editor}

Renata Silva de Carvalho Chinelato

Technical support

Vitória Batista Santos Silva

\section{EDITORIAL PRODUCTION}

Publishing coordination

Jéssica Dametta

Graphic designer

Libro

Language editor

Daniel de Almeida Leão

Layout designer

Emap 